\title{
Versoek om bydraes: Spesiale uitgawe van \\ SA Tydskrif vir Natuurwetenskap en Tegnologie (28(4), Desember 2009): Die uitdaging van ontoereikende Wiskundeprestasie: Fokus op probleemoplossing
}

Daar bestaan wêreldwyd kommer oor ontoereikende prestasie in wiskunde en Suid-Afrika is geen uitsondering op hierdie reël nie. Inteendeel - Suid-Afrikaanse kenners spreek toenemend hul kommer uit oor veral Graad-12-leerders se ontoereikende prestasie in Wiskunde en die impak hiervan op sowel tersiêre studie as die nasionale ekonomie (Simkins, Rule, \& Bernstein, 2007). Die negatiewe effek van ontoereikende Wiskundeprestasie op die ekonomie is immers haas onberekenbaar. Tensy daar genoeg beroepslui soos ingenieurs opgelei word, kan die ekonomie eenvoudig nie vinnig genoeg groei nie.

Die transformasie van onderwys in Suid-Afrika ten spyt is die wiskundeslaagsyfer op skool, maar ook op universiteit onaanvaarbaar laag. Om die waarheid te sê, om in wiskunde te presteer beteken oorlewing vir individuele leerlinge, maar ook vir enige ontwikkelende land. Dit is dalk nie vergesog om te beweer onderprestasie in wiskunde in die land is 'n nasionale ramp nie (Maree, 2008; Rademeyer, 2008).

Alhoewel onderwys en opleiding in postapartheid Suid-Afrika getransformeer word, bly die druipsyfer vir wiskunde op skool onaanvaarbaar hoog (Maree, Pretorius \& Eiselen, 2003; Steyn \& Maree, 2003). Die situasie is veral kommerwekkend in township- en plattelandse skole en daar word geskat dat ongeveer een uit elke 200 swart leerders Wiskunde met 'n C in die hoër graad slaag. Vrae word verder gevra oor die toepaslikheid al dan nie van die Uitkomsgerigte Onderwysstelsel, wat klaarblyklik (nog) nie die resultate lewer waarop gehoop is nie.

Ontoereikende prestasie in Wiskunde behoort verder deurentyd geïnterpreteer te word teen die verwysingraamwerk van leerders wat daagliks gekonfronteer word met toenemende eise om massas inligting te verwerk en te kan toepas in 'n Suid-Afrikaanse samelewing waar die werkloosheidsyfer buitengewoon hoog is.

Suid-Afrikaanse onderwysinstellings, wat genoop word om deurlopend te besin oor hul aard en doelstellings in 'n poging om leerders toereikend voor te berei op ' $n$ veranderende wêreld, worstel boonop tans met die probleem om 'n groter persentasie leerders gereed te kry vir tersiêre studie, maar ook sukses te behaal aan tersiêre instellings. Wiskunde, by verre die vernaamste keuringsvak; dié vak wat aan leerders toegang bied tot gesogte studierigtings, verdien hier spesiale vermelding. Navorsing bring verder aan die lig dat digby $40 \%$ van alle eerstejaarstudente jaarliks hul eerstejaar druip (by uitstek leerders uit tradisioneel benadeelde gemeenskappe (Mkhabela, 2004; Pandor, 2004) en dat ontoereikende prestasie in natuurwetenskaplike studierigtings veral kommer wek. Hierdie prentjie is selfs donkerder indien in ag geneem word dat slegs ongeveer $20 \%$ van alle Suid-Afrikaanse tersiêre studente gradueer (Ntshwanti-Khumalo, 2003).

In aansluiting hierby beklemtoon Pistorius (in Rademeyer, 2005(a)) dit dat daar landwyd kommer bestaan oor die wiskundige en taalvaardigheid van nuwe eerstejaarstudente. Schlemmer (in Rademeyer, 2005(b)) wys weer daarop dat 'n halfmiljoen Suid-Afrikaanse leerders steeds geen klaskamers het nie, terwyl slegs 5\% van die matrikulante wiskunde in die hoër graad slaag en 32\% in die standaardgraad. Hy wys verder daarop dat $20 \%$ van alle skole nie eens wiskunde as vak aanbied nie en meen dat die verbeteringe wat hul oor die afgelope aantal jaar ten opsigte van die matriekslaagsyfer gemanifesteer het, bloot kosmeties is, aangesien die aantal matrikulante wat matriek skryf, tussen 1998 en 2004 met sowat $17 \%$ gedaal het.

Die probleem van onderprestasie in Wiskunde ontstaan klaarblyklik vroeg in leerders se loopbane. Die eerste graad 3-evaluering in 2001 het in hierdie verband aan die lig gebring dat leerders veral ten 
opsigte van syfervaardigheid ontoereikend gepresteer het en dat aggressiewe ingryping nodig is ten einde die situasie te verbeter (Bot, 2005). Leerders het 'n gemiddelde persentasie van 30\% behaal (DoE, 2002). Hierbenewens het die (TIMMS-R) na wêreldwye tendense in skolastiese prestasie in wiskunde en wetenskap bevestig dat Suid-Afrikaanse wiskunde-leerders se prestasie beduidend swakker was as dié van die meeste ander deelnemende lande wat deur toetse in basiese wiskundevaardighede gemeet is (Howie, 2001). Suid-Afrika het selfs beduidend swakker gevaar as die twee ander Afrika-lande wat aan die opname deelgeneem het, naamlik Marokko en Tunisië. SuidAfrikaanse leerders het veral gesukkel met taalprobleme. Oor die algemeen het die leerders baie probleme ervaar met die kommunikering van hul antwoorde in die taal van die toets (Engels) en het hulle getoon dat hul nie oor die vereiste basiese wiskundige kennis beskik nie.

Dit is teen hierdie agtergrond dat ons hierdie oproep om bydraes tot alle belanghebbendes rig. Ons sal graag verskillende tipes voorleggings, sowel langer (ca. 5000 woorde) as korter (ca. 1 500-2 500) oorweeg, byvoorbeeld navorsingsartikels, oorsigartikels, asook "gesprekstukke". Neem asseblief egter kennis dat ons meer geïnteresseerd in bydraes waarin moontlike oplossings vir die uitdaging van ontoereikende Wiskundeprestasie, gevolg deur nie-toelating tot gesogte studievelde, beperkte werksgeleenthede en ingeperkte nasionale groei uitspel as in bydraes wat maar net nog 'n keer die "krisis in Wiskunde-onderwys" uitstippel. Is 'n deel van die oplossing byvoorbeeld daarin geleë dat Wiskunde-onderwysers aansienlik beter vergoed word as ander onderwysers? Is die massiewe bedrae wat in Dinalediskole belê word 'n goeie idee of behoort tradisioneel "bevoordeelde" ("elite"-)skole met 'n bewese prestasierekord eerder gesteun te word om meer leerders oor die diversiteitspektrum heen in te neem en te help om beter te presteer in wiskunde (Simkins, Rule, \& Bernstein, 2007)? Help ons soek na oplossings!

\section{BIBLIOGRAFIE}

Bot, M. (2005). School education in South Africa: tracking change over ten years. Edusource Data News, 46, $1-10$.

Department of Education (2002). Draft education for all status report 2002: South Africa, incorporating country plans for 2002 to 2015. (Government Printers, Pretoria).

Howie, S. (2001). Mathematics and science performance in Grade 8 in South Africa. 1998/1999. (Human Sciences Research Council, Pretoria).

Maree, J.G. (2008). Why maths counts. Quest, 493), 38-45.

Maree, J. G., Pretorius, A., \& Eiselen, R. E. (2003). Predicting success among first-year engineering students at the Rand Afrikaans University. Psychological Reports, 93, 399-409.

Mkhabela, M. (26.09.24). Failure rate for black students 'horrifying'. City Press, 6.

Nthswanti-Khumalo, T. (2003). A tertiary update: October 2002 - September 2003. Edusource Data News, 42, 1-20.

Pandor, N. (2004). Maths today and tomorrow. Toespraak van Minister Naledi Pandor by geleentheid van die opening van die 9e Wiskundekongres (AMESA). Potchefstroom, 1 Julie 2005.

Rademeyer, A. (22.09.2008). Slaagsyfer vir wiskunde te laag - kenner. Beeld, 9.

Rademeyer, A. (25.06.2005(a)). SA gaan ly oor te min geld vir hoër onderwys. Beeld, 7.

Rademeyer, A. (25.06.2005(b)). Afrikaners al hoe vieser vir hul skole. Beeld, 7.

Simkins, C., Rule, S, \& Bernstein, A. (2007). Doubling for growth. (Centre for Development and Enterprise, Johannesburg.).

Steyn, T.S., \& Maree, J.G. (2003). Study orientation in mathematics and thinking preferences of freshmen engineering and science students. Perspectives in Education, 21, 47-57. 